\title{
Flexural Strength of Self-Compacting Concrete Beams
}

\author{
Amiruddin Amiruddin ${ }^{1,}$ Ibrahim Ibrahim $^{1}$, Ika Sulianti $^{1}$, Agus Subrianto $^{1, *}$, \\ Muhamad Ramadhan ${ }^{1}$, Tiara Novia Khuljanna ${ }^{1}$
}

\author{
${ }^{1}$ State Polytechnic of Sriwijaya \\ *Corresponding author. Email: agussubrianto@gmail.com
}

\begin{abstract}
Concrete precast technology has been developing and already used for many building structures. The components that have thin dimensions sometimes have problems in casting like its flowing and compaction. Self-Compacting Concrete (SCC) does not need to vibrate to achieve full compaction and it can flow to reach the narrow side of concrete formwork. This study used a mix design to perform SCC beams with added material in the form of superplasticizer viscocrete with levels of $1.2 \%, 1.3 \%, 1.4 \%, 1.5 \%$ and $1.6 \%$ of the cement weight. For each variation of the composition, 3 specimens were made, each variation of the specimen was made for 14 days, 21 days, and 28 days tests. From the test results, fresh concrete has met the requirements for SCC concrete, but for the strength test and superplasticizer variations $1.2 \%, 1.3 \%, 1.4 \%, 1.5 \%$ and $1.6 \%$ have not met the requirements set by SCC. In this study, the highest average compressive strength value obtained at $1.6 \%$ superplasticizer percentage, which was $28.31 \mathrm{MPa}$ with the highest average flexural strength value at $1.6 \%$ superplasticizer percentage, which was $2.97 \mathrm{MPa}$.
\end{abstract}

Keywords: Flexural Strength, Precast Concrete, Beam Panel, Self-compacting Concrete, Viscocrete.

\section{INTRODUCTION}

Pouring concrete is one of the essential step on concrete construction project. This stage spends big portion of progress and of course the resources. In traditional concreting work, many labours work on construction site, and sometimes they are unskilful to produce an adequate specification. The effort to compact the fresh concrete required both men and machine. Further, casting the thin structural element, such as thin wall and slab is quite different from larger elements. The development of the precast technology also feel necessity to achieve well-poured concrete because it has thin elements too, for instance: modular house system and precast bridge girder. Inadequate concrete compacting brings concrete defect, such as honeycomb that lead the decrease of concrete strength.

To find out these problems, it ought to apply any material that has good characteristic for bending and easy to flow so it can reach the narrow formwork without excessive intervention from labours. It is well known, self-compacting concrete (SCC) or selfconsolidating concrete is a special type of concrete which can be placed and consolidated under its own weight without any vibration effort due to its excellent deformability, and which at the same time is cohesive enough to be handled without segregation or bleeding. Self-consolidating concrete has been already used for building, bridge, and tunnel [1].

Several researches to investigate the behavior of SCC has been performing since decades until now. The SCC's mechanical properties depends on various factors, such as aggregate [2], binder, powder [3], and temperature [4].

The essential characteristic of SCC is its capability to flow into the formwork. However, the hardened state of concrete is the final purpose. Previous research on SCC that investigated quite high of compressive strength of concrete, ranged on 40 to $80 \mathrm{MPa}$ [1]. One of the mechanical property of SCC is flexural strength. Another research was also performed to examine flexural strength of reinforced concrete beam. The addition of silica fume until certain percentage increases the flexural strength of concrete [5]. The SCC beam with addition of silica fume and metacaolin tends to have higher performance on load obtained and crack width compared to conventional concrete [6]. The aspect ratio and volume fraction of fibres increase the flexural strength of SCC beams [7]. The study also shows that incorporated industrial waste such as limestone and marble powder into SCC mixes can 
augment the flexural strength [8]. However, the proposed study needs to investigate the flexural strength of SCC which formula used in Japan [1], using local material to see if the local characteristic produce different behaviour on SCC mixes.

\section{METHOD}

This research use Portland cement type 1, water, sand, stone ash, and sharp stone as materials. The high range water reducer type $\mathrm{F}$ is added to produce the easy flow concrete. Material properties is the initial stage before making SCC concrete. It consists of several tests, namely: sieve analysis, specific gravity and aggregate absorption, aggregate density, moisture content, and aggregate silt content. Furthermore, the mixed is carried out based on a mixture from the Japanese $\mathrm{J} 2$ mixture [1]. The content of superplasticizer are $1.2 \%, 1.3 \%$, $1.4 \%, 1.5 \%$ and $1.6 \%$ by weight of cement. For each variation of the composition. L-box, V-tunnel and inverted Abram cone to evaluate the slump flow, passing ability and segregation resistance[9].

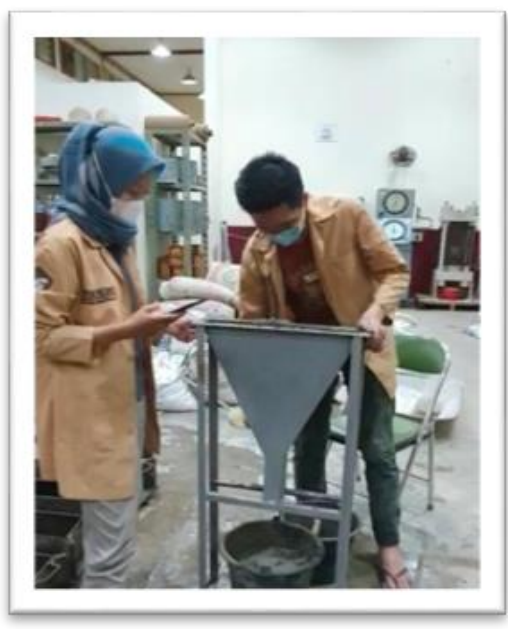

Figure 1. V-funnel test

Table 1 shows the composition of mixture used in this study based on $\mathrm{J} 2$ mixture.

Table 1. Mixed design

\begin{tabular}{|l|c|}
\hline Ingredients & Value (kg) \\
\hline Water & 165 \\
\hline Cement & 220 \\
\hline Fly ash & 0 \\
\hline Stone dust & 220 \\
\hline Furnace slag & 0 \\
\hline Sand & 870 \\
\hline Coarse aggregates & 825 \\
\hline HRWR & 4.4 \\
\hline VMA & 4.1 \\
\hline
\end{tabular}

In this study, the sample used was cylindrical with a height of $30 \mathrm{~cm}$ and a diameter of $15 \mathrm{~cm}$ tested by ASTM standard [10], for testing the flexural strength used a beam-shaped sample of $15 \times 15 \times 60 \mathrm{~cm}$ [11]. The specimen were casted for three testing times, namely 14 days, 21 days, and 28 days, so total of specimens are 54 for each cylinder and beam.

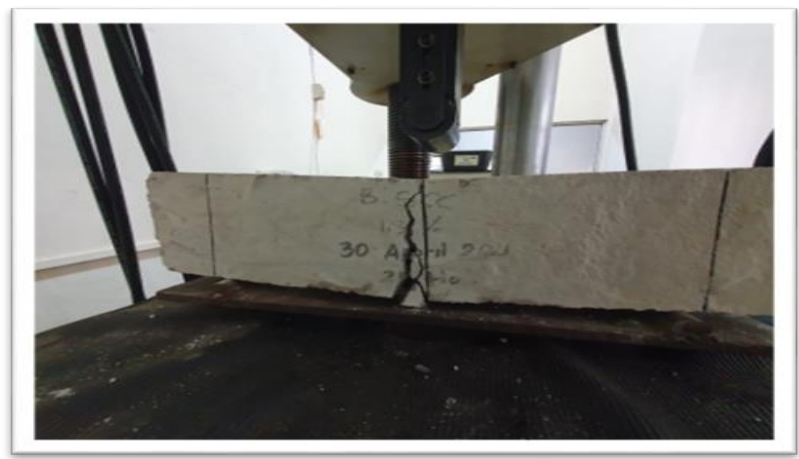

Figure 2. Flexural test

\section{RESULTS AND DISCUSSION}

\subsection{Fresh concrete}

SC flowing tests shows that the slump flow for SCC are wider than $600 \mathrm{~mm}$, the passing ability ranges from 0.8 to 1 and segregation resistance ranges from 8 to 12 seconds. All of these values meet the requirements.

Table 2. Result of flow tests

\begin{tabular}{|l|c|c|c|}
\hline \multirow{2}{*}{ SP content (\%) } & \multicolumn{3}{|c|}{ Values } \\
\cline { 2 - 4 } & $\begin{array}{c}\text { Slump } \\
\text { flow } \\
(\mathrm{mm})\end{array}$ & $\begin{array}{c}\text { Passing } \\
\text { ability } \\
(\mathrm{H} 2 / \mathrm{H} 1)\end{array}$ & $\begin{array}{c}\text { Segregation } \\
\text { resistance } \\
\text { (second) }\end{array}$ \\
\hline 0 & 550 & 0.615 & 12.58 \\
\hline 1.2 & 670 & 0.916 & 8.03 \\
\hline 1.3 & 655 & 0.875 & 9.21 \\
\hline 1.4 & 635 & 0.83 & 10.65 \\
\hline 1.5 & 645 & 0.833 & 10.14 \\
\hline 1.6 & 660 & 0.869 & 9.58 \\
\hline Requirement & 660 & $0.8-1$ & $8-12$ \\
\hline
\end{tabular}

\subsection{Compressive strength}

Figure 3 illustrates the compressive strength of concrete versus superplasticizer content. It can be clearly seen that the compressive strength gradually increase from zero SP to $1.3 \%$ of SP. After that point, the value is relative plat even increase and in the end it increase significant for $1.6 \%$ of SP at $28.3 \mathrm{MPa}$. These results are below the compressive strength for original mixture, ranged 40 to $80 \mathrm{MPa}$ [1]. It may different because the index properties of local materials differs from the Japanese constituents. 


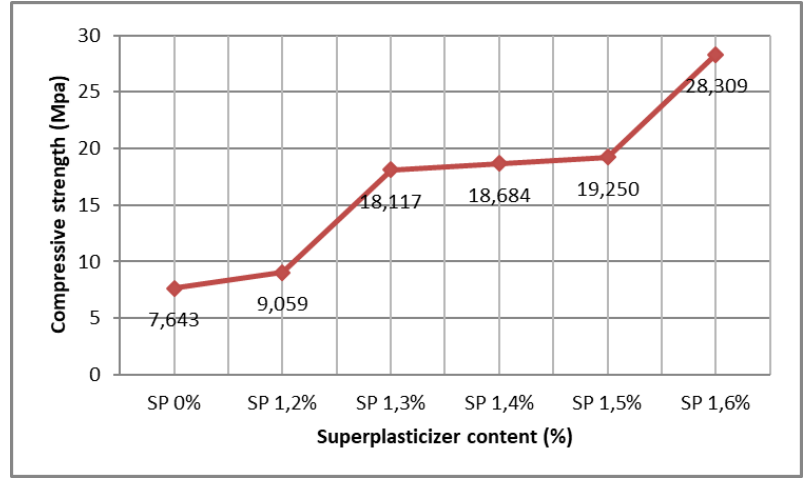

Figure 3. Compressive strength

\subsection{Flexural strength}

The development of the graph has almost similar shape for modulus of rupture. The flexural strength escalates since more SP added in mixture. Figure 4 shows that the higher modulus of rupture of concrete beam is $2.97 \mathrm{MPa}$ was reached at $1.6 \%$ of superplasticizer content.

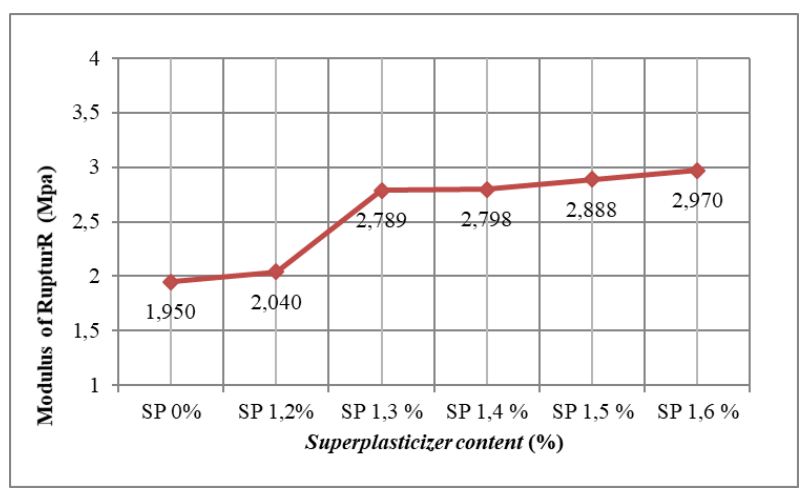

Figure 4. Modulus of Rupture

For normal concrete, the modulus of rupture of concrete usually $0.62 \sqrt{f_{c}^{\prime}}$. Figure 4 presents that the coefficient ranges closely to 0.62 and it continues decrease since the SP content increases.

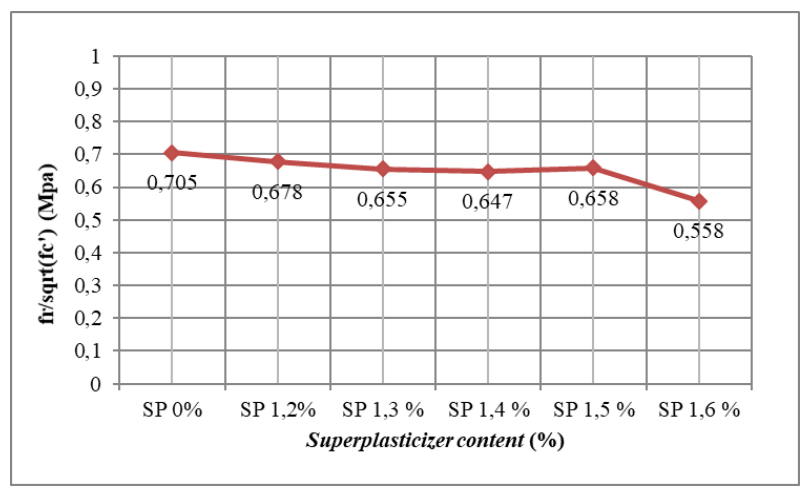

Figure 5. Modulus of Rupture Constant

\section{CONCLUSION}

After doing the laboratory experimental, the following statements can be drawn:

1. Concrete with Super plasticizer type F addition has reached Self compacting concrete criterions and indicates that it can flow easily in the formwork, thus will reduce the compaction effort;

2. The compressive strength of concrete increases as the percentage of super plasticizer;

3. The flexural strength of concrete increases as the percentage of super plasticizer;

4. The adopted mix formula is not clearly matching for local material application on compressive and flexural strength of concrete.

For further research, it is interesting to find the composition to meet higher level of both compressive and flexural strength of concrete.

\section{ACKNOWLEDGMENTS}

The Authors thank to Ministry of Education and Culture of Republic of Indonesia to support this research through State Polytechnic of Sriwijaya annual funding.

\section{REFERENCES}

[1] M. Ouchi, S. Nakamura, T. Osterberg and S. E. Hallberg, M. Lwin., "Applications of selfcompacting concrete in japan, europe and the United States" vol. 49, pp. 1-33, 2003.

[2] V. Revilla-Cuesta, F. Faleschini, M. A. Zanini, M. Skaf, and V. Ortega-López, "Porosity-based models for estimating the mechanical properties of self-compacting concrete with coarse and fine recycled concrete aggregate," J. Build. Eng., vol. 44, no. October, p. 103425, 2021, doi: 10.1016/j.jobe.2021.103425.

[3] V. Revilla-Cuesta, M. Skaf, A. B. Espinosa, and V. Ortega-López, "Multi-criteria feasibility of real use of self-compacting concrete with sustainable aggregate, binder and powder," J. Clean. Prod., vol. 325, p. 129327, 2021, doi: 10.1016/j.jclepro.2021.129327.

[4] N. Garcia-Troncoso, L. Li, Q. Cheng, K. H. Mo, and T. C. Ling, "Comparative study on the properties and high temperature resistance of selfcompacting concrete with various types of recycled aggregates," Case Stud. Constr. Mater., vol. 15, no. August, p. e00678, 2021, doi: 10.1016/j.cscm.2021.e00678.

[5] C. Rajendra Prasath, D. Vivek, K. S. Elango, and R. Dharmaraj, "Experimental Investigations on Flexural Behaviour of Self Compacting Concrete Beam with Silica Fume," IOP Conf. Ser. Mater. Sci. Eng., vol. 1145, no. 1, p. 012101, 2021, doi: 
10.1088/1757-899x/1145/1/012101.

[6] M. Marshaline Seles, R. Suryanarayanan, S. S. Vivek, and G. Dhinakaran, "Study on Flexural Behaviour of Ternary Blended Reinforced Self Compacting Concrete Beam with Conventional RCC Beam," IOP Conf. Ser. Earth Environ. Sci., vol. 80, no. 1, 2017, doi: 10.1088/17551315/80/1/012026.

[7] A. M. Saba et al., "Strength and flexural behavior of steel fiber and silica fume incorporated selfcompacting concrete," J. Mater. Res. Technol., vol. 12, pp. 1380-1390, 2021, doi: 10.1016/j.jmrt.2021.03.066.

[8] Y. Subramaniyan, J. Baskaran, and N. K. Krishnaswami, "Utilization of Industrial Wastes in Manufacture of Self Compacting Concrete and
Examining Its Flexural Behaviour," IOP Conf. Ser. Mater. Sci. Eng., vol. 955, no. 1, 2020, doi: 10.1088/1757-899X/955/1/012044.

[9] ASTM C1611/C1611M-18, "Standard Test Method for Slump Flow of Self-Consolidating Concrete," ASTM Int., vol. i, p. 6, 2018.

[10] C. C. Test, T. Drilled, C. C. Test, and B. Statements, "Standard Test Method for Compressive Strength of Cylindrical Concrete Specimens 1," pp. 3-9, 2014, doi: 10.1520/C0039.

[11] American Society for Testing and Materials (ASTM), “Astm C78/C78M -18:," Stand. Test Method Flexural Strength Concr. (Using Simple Beam with Third-Point Loading)ASTM Int. USA, vol. 04.02, pp. 1-3, 2002. 